International Journal of Business and Management Review

Vol.8, No.5, pp.28-43, August 2020

Published by ECRTD-UK

Print ISSN: 2052-6393(Print), Online ISSN: 2052-6407(Online)

\title{
DIVIDEND POLICY AND PROFITABILITY OF AGRO ALLIED COMPANIES IN NIGERIA
}

\author{
Dr Seini Odudu ABU \\ Department of Accounting, \\ Faculty of Management Sciences, \\ Federal University Dutsin-Ma, \\ Katsina State Nigeria \\ +2347039006118; 2348036136823 . \\ Mr James Uchenna OKPE \\ Department of Accounting, \\ Faculty of Management Sciences, \\ Federal University Dutsin-Ma, \\ Katsina State Nigeria \\ $+2348035957892$
}

\begin{abstract}
This study assesses the effect of dividend policy on the profitability of listed agroallied companies in Nigeria. The population of the study consists of five (5) listed agro-allied companies on the Nigerian Stock Exchange as at 31/12/2018. All the listed agro-allied firms were used due to the small sample size. Secondary data were collected from the sampled firms through their published audited financial statements for 14 years ranging from 2005-2018. The ex-post facto research design was adopted with regression and descriptive analysis to determine the effect of explanatory variables. The results show that the return on assets has a positive and significant effect on dividend policy of listed agro-allied companies in Nigeria, while return on equity has a negative and significant effect on dividend policy of listed agro-allied companies in Nigeria but earnings per share have a negative and insignificant effect on dividend policy of listed agro-allied companies in Nigeria. Based on the findings, the study concludes that the dividend policy has the probability of influencing the profitability of listed agro-allied companies in Nigeria. The study, therefore, recommends that firms should adopt policy and strategy on efficient use of company assets that would enable them to generate profits to meet up with dividends payment regularly to attracts more investors. This is because investors assume that a firm which pays dividend regularly is evidence that a company is healthy financially.
\end{abstract}

KEYSWORD: return on assets, return on equity, earning per share, dividend payout ratio, and dividend retention ratio.

\section{INTRODUCTION}

The globalization, commercialization and privatization in the business environment have brought a great rivalry in every field of activity. This had made it impossible for companies to compete in 
the markets. To bridge the gap and to add value to the shareholders' wealth and companies, management of most companies has to make critical financial decisions. These decisions will help the companies to achieve the long-run objective of shareholders wealth maximization as they (shareholders) would like their wealth to be placed at the market price of the company's common stock (Matengo, 2008).

At first, the management of the company may seem that a company could always give back as much as possible to its shareholders by paying a cash dividend. On the other hand, the management of the company might seem that a company could always invest the money for its shareholders instead of paying it out. These two financial decisions are critical and important to the survival of any company. The financial decision lead to the question: should the company pay out money to its shareholders or should it keep that money, invest it and payback later to its shareholders? Structuring dividend decision whether to pay out or to plough back and reinvest it has been a debatable issue both theoretically and empirically, and there was no consensus among the scholars (uwuigbe, jafaru, \& Ajayi 2013).

Selecting the suitable dividend policy is a vital decision for the company because the decision to pay or not to pay dividend may promote a company and may also crash the company. Also, the gateway to investing in future projects depends on the amount of dividend that they pay currently to their shareholders. This suggests that the payment of the dividend is very important to investors. Furthermore, shareholders believed in the maximization of their return and this return may be in the form of dividends or capital gain. Therefore dividend decisions are vital instruments as they determine what funds flow to shareholders and what funds are plough back by the firm for investment (uwuigbe et al, 2013). Thus, dividend policy is the dependent variable and the payment of dividends depends on the profit generated by the company.

Profitability is the cornerstone or livewire of every business, being it small, medium or large. The ability of any company to operate effectively depends upon the profit which it generates. When a company's profitability turns low, no amount of miracles or magic that can make the company perform better. The low profit would have a significant impact on dividend payout decisions. However, when a company earns higher profit, it will decide to give higher back to the shareholders who are the owners of the company (Sartaw, 2008). Hence, the study has taken profitability as an independent variable measured by return on assets (ROA) return on equity (ROE) and earnings per share (EPS).

The agricultural sector is one of the backbones of Nigeria's economy and the agricultural companies contribute immensely to gross domestic product (GDP) growth as it ensures food security as well as part of the major creator of employment opportunities. Many firms globally including Nigeria in the sector have experienced hard times in the past even till date based on fluctuating government policies couple with the current epidemic called Cov 19. This caused the sector .to witnessed the mass migration of people especially the youth leaving agriculture and embarking on the white-collar job thus making the sector at the more deplorable state 
Generally, there are arguments and counter-arguments as regards the policy of dividend payment. This has post challenging for the directors and financial manager of most companies because different investors have different views on present cash dividends and future capital gains. Some investors believe that bird at hand is more than millions in the bush (Abu \& Emmanuel, 2019), suggesting that payment of dividend now is better and valuable to investors than retained and reinvested in the future. While others view that retaining and reinvesting it pays much better and add value to the investor's investment than redistribute it regularly. This has resulted in dividend payment relevancy (Brigham, 1995; Litzenberger \& Ramaswamy, 1979), and dividend payment irrelevancy (Black \& Scholes, 1974; Modgliani \& Miller, 1961). Therefore, no consensus has yet emerged by scholars after several decades of researches theoretically and empirically.

The payment and non-payment of dividend also have its effect on the share price as higher dividend payment communicates to the investors the increase market value of shares, while nonpayment or lower dividend also communicates to the investors a decrease market value of shares (Abu \& Emmanuel, 2019). Due to this controversial nature of a dividend policy, the Nigerian government had initiated a series of policies and programs which were aimed at restoring the agricultural sector to its pride of place in the economy. However various efforts at promoting investment and export diversification in the agricultural sector have not yielded appreciable dividend. This has resulted to a series of problems such as inadequate storage facilities, a lowlevel commitment of top management, ineffective marketing planning, levels of insecurity in the country, poor infrastructural system, dormant research facilities, education and modernization and inconsistent government policies among others. These to a large extent had played a significant role in destabilizing the agricultural sector in the country, thereby resulting in low levels of operation, which in turn lowers the levels of profitability and invariably affecting the dividend policies of the agro-allied firms. It is against this background that the study sought to examine the impact of profitability on dividend policy of listed agro-allied firms in Nigeria.

The main objective of this study is to examine the effect of dividend policy on the profitability of listed agro-allied companies in Nigeria. To accomplish this, the study evaluates the effect of return on assets (ROA) on dividend policy of listed agro-allied companies in Nigeria; assess the effect of return on equity (ROE) on dividend policy of listed agro-allied companies in Nigeria, and ascertain the effect of earnings per share (EPS) on dividend policy of listed agro-allied companies in Nigeria.

The following hypotheses were formulated and tested:Ho1: Return on assets (ROA) has no significant effect on dividend policy of listed agro-allied companies in Nigeria; H02: Return on equity (ROE): has no significant effect on dividend policy of listed agro-allied companies in Nigeria; and H03: Earnings per share (EPS) has no significant effect on dividend policy of agroallied companies in Nigeria. 


\section{LITERATURE REVIEW}

The concept of dividend policy and profitability was developed as a base for the decision whether or not profit made from the business transaction by the organization after all expenses incurred were deducted would be distributed to the shareholders in form of dividend or plough back to the organization for reinvestment (Enekwe, Nweze \& Agu 2015). This is the highest decision management of most companies is facing regarding the revenues to be distributed to the shareholders for their investment in the company. However, a decision on dividend policy and profitability remains a source of debating despite its establishment as a base for distributing or not distributing profits. To bridge the gap in the literature on the impact of dividend policy and profitability, the study evaluates the impact of dividend policy on the profitability of listed agroallied companies in Nigeria, considers dividend payout ratio and dividend retention ratio which appears on the centre as a dependent variable, return on assets (ROA), return on equity (ROE), and earnings per share (EPS) on the left-hand side as independent variables, while leverage and age on the right-hand side as a control variable. Table 1 below shows the conceptual framework for the study.

Table $1 \quad$ Dividend Policy and Profitability

\begin{tabular}{llll}
\hline & Profitability & Dividend policy & Control variables \\
\hline 1 & Return on assets (ROA) & 1 Dividend payout ratio & 1 Leverage \\
& & 2 & 2 Firm age \\
2 & Return on equity (ROE) & 2 Dividend retention ratio &
\end{tabular}

3 Earnings per share (EPS)

Source: Built by Author Base on Literature

The above conceptual framework was developed to ascertain the association between the independent and dependent variables. The independent variable comprises of return on assets (ROA), return on equity (ROE), and earnings per share (EPS), the dependent variable was measure by dividend payout ratio and dividend retention ratio, while leverage and firm age were used as control variables.

The dividend payout ratio is the ratio of the total amount of dividends paid out to shareholders relative to the net income of the company. It is the percentage of earnings paid to shareholders in dividends. Dividend payout ratio indicates how much money a company is returning to shareholders versus how much it is keeping on hand to reinvest in growth, pay off debt, or add to cash reserves (retained earnings). It is calculated as dividend payout $=$ Net income $\div$ Dividend paid. Dividend retention, on the other hand, refers to the percentage of net income that is retained to grow the business, rather than being paid out as dividends. It is the opposite of the payout ratio, which measures the percentage of profit paid out to shareholders as dividends. It is the proportion of earnings kept back in the business as retained earnings. It is calculated as the dividend retention ratio $=1$ - dividend payout ratio. 
International Journal of Business and Management Review

Vol.8, No.5, pp.28-43, August 2020

Published by ECRTD-UK

Print ISSN: 2052-6393(Print), Online ISSN: 2052-6407(Online)

Return On Assets (ROA), according to Van Horne and Wachowicz (2005) is an indication of the profitability of the assets of the firm after all expenses and taxes. It is a common measure of managerial performance of a firm (Ross, Westerfield \& Jaffe 2005). It measures how much the firm is earning after tax for each naira invested in the assets of the firm. This means, it measures net earnings per unit of a given asset to determine, how insurance companies can convert their assets into earnings (Samad \& Hassan 2000). ROA is calculated as ROA = Net Profit after Tax / Total Asset. The return on equity is a measure of the profitability of business concerning the equity, also known as net assets or assets minus liabilities. ROE is a measure of how well a company uses investments to generate earnings growth. Return on equity (ROE) is a ratio that provides investors with insight into how efficiently a company (or more specifically, its management team) is handling the money that shareholders have contributed to it. It is calculated as $\mathrm{ROE}=$ Net Income $\div$ Total Equity. While earning per share (EPS) on the other hand is the portion of a company's profit allocated to each outstanding share of common stock. Earnings per share serve as an indicator of a company's profitability (Van Horne \& Wachowicz, 2005) . EPS is calculated as EPS = (Net Income - Dividends on Preferred Stock) / Average Outstanding Shares. It is also an indication that how much a company is making in profits per every outstanding share.

Numerous theories account the association between profitability and dividend policy. This study considers five theories: bird in hand theory, irrelevancy theory, signalling theory, residual theory, and agency cost theory. The bird in hand theory postulates that a bird in hand is worth forty million in the bush (Easterbrook,1984 in Abu \& Emmanuel, 2019), suggesting that investors prefer dividends from stock to potential capital gains because of the inherent uncertainty associated with capital gains. This also suggests that investors prefer the certainty of dividend payments to the possibility of substantially higher future capital gains as the future is pregnant whether it will give birth to a child alive, death or aborted. Dividend irrelevancy theory (Modigliani \& Miller,1961) posits a contrarily view that payment of a dividend has no impact on stock price and cost of capital and dividend policy of a firm becomes trivial for shareholders wealth. This shows that investors may not concerned about a company's dividend policy since they can sell part of the portfolio of their equities if they want cash. If they don't want cash, they can use dividends to buy stock. The theory implied that, if dividends are irrelevant, firms would spending a great deal of time pondering an issue about which of their stockholders is indifferent.

Dividend signalling theory postulates that announcement of an increase in dividend payouts by the company to its shareholders is an indication of positive prospects. This is because stock prices tend to rise when a company announces an increase in dividend payouts and fall when dividends are to be decreased. This suggests that if a company announces a decrease dividend payout or announces the intention not to pay a dividend, it will affect the stock price as well as the firm value because it is bad news (Poterba \& Lawrence,1985). Agency theory postulates the relationship between principals and agents, whereby the principal engages the agent to perform some service on his/her behalf he/she delegating some decision making authority to the agent (Jensen \& Meckling,1976). The theory suggests that payment of dividend keeps firms in the capital market, where monitoring of managers is available at a lower cost. This theory implies 
that if the firm is paying out dividend consistently, the service of a third party (auditors) to monitor the managers would not be necessary thereby reduces the agency cost.

While the residual theory of dividend policy holds that the firm will only pay a dividend from residual earnings, suggesting that the dividends should be paid only if funds remain after the optimum level of capital expenditures is incurred. The primary focus of the firm is on investments and hence dividend policy is a passive decision variable this theory implies that the value of a firm is a direct function of its investment decisions thus making dividend policy irrelevant. Considering all these theories, the study anchored on bird in hand theory on the view that one cannot give out what he/she don't have in respect of investors' preference for the certainty of dividend payment to the possibility of substantial higher future capital gains. Suggesting that organizations can only distribute dividends based on the availability of resources putting into consideration other factors before distribution of such dividend.

Akani and Swenene (2016) investigate the association between dividend policy and profitability in Nigeria. The study sample 15 companies out of the total of 24 companies listed on the Nigerian Stock Exchange for the year 2009 to 2014. The dependent variable was dividend policy measured by dividend payout and dividend yield, while the independent variable was profitability proxies by earnings per share and return on equity. The findings revealed that all the independent variables have a positive and significant association with the dependent variable. In the same vein, Calistus, Mohammed and David (2018) assesses the impact of dividend policy on profitability in Nairobi. The study sample all the 7 agricultural firms listed in the Nairobi Stock Exchange for the year 2010. Multiple regression techniques were used to analyze the data. The findings show a negative and insignificant impact of dividend policy on profitability.

Anandasayanan and Velnampy (2016) evaluate the relationship between dividend policy and corporate profitability in Sri Lanka. The study population consists of all the 23 listed manufacturing firms in Sri Lanka Stock Exchange for the year 2009 to 2014. The independent variable was profitability proxies by return on assets and return on equity. The dependent variable was dividend policy measured by dividend payout ratio and dividend yield. Ordinary least square (OLS) regression was utilized to analyze the data. The findings show a positive and significant relationship between dividend policy and corporate profitability. Similarly, Evans and Hadrat (2016) examine the effect of profitability on dividend policy in Kenya. The study population consists of all the manufacturing firms listed in Kenya from 2011 to 2015. The independent variable was profitability proxies by liquidity, earnings per share and company size, while the dependent variable was dividend policy measured by dividend payout. Linear regression technique was used to analyze the data. The study reveals a negative and significant effect of dividend policy on profitability.

Faraz, Ishfaq and Khan (2017) investigates the impact of dividend policy on shareholders wealth and firm performance in Pakistan. The study population comprised of 51 firms in Pakistan Stock Exchange for the year 2006 to 2015. Dividend per share and dividend yield were used as measured of dividend policy. Earnings per share and share price were proxies for shareholders wealth, while return on equity was proxy for firm performance. Multiple regression was utilized 
for data analysis with 510 firm-year observations. The findings show a positive and significant impact of dividend policy on shareholders wealth and firm performance. In the same vein, Geoffrey (2017) examines the effect of dividend policy on financial performance in Nairobi. The study sample 31firms out of the total of 46 firms listed on the Nairobi Securities Exchange for the period 2005 - 2015. The financial performance was the independent variable proxies by return on equity, cash flows, market to book value and price-earnings. The dividend policy was the dependent variable measured by the interim to total dividend ratio and dividend payout ratio. Multiple regression was utilized for data analysis. The findings show a negative and significant effect of dividend policy on financial performance.

Monoarfa (2018) assesses the role of profitability in mediating the effect of dividend policy in Indonesia. The study population comprised all the 45 companies listed on the Indonesian Stock Exchange for the year 2014 - 2016. Dividend policy was the dependent variable measured by dividend payout and price per book values, while the independent variable was profitability proxy by return on assets. Spatial least square (SLS) regression was utilized for data analysis. The results revealed a negative and significant effect of dividend policy on profitability. Likewise, Chauhan, Ansari, Taqi, and Ajmal (2019) evaluate the impact of dividend policy on profitability in India. The study population consists of 10 information technology (IT) companies listed on the Bombay Stock Exchange for the period 2012 to 2017. Dividend policy was the dependent variable measured by dividend payout ratio, earnings per share and price-earnings ratio. Profitability was the independent variable proxies by return on assets and return on equity. Correlation matrix and panel regression were used for data analysis. The findings show a positive and significant impact of dividend policy on profitability.

Idewele and Murad (2019) examine the relationship between financial performance and dividend policy in Nigeria. The study population comprised of 15 listed deposit money banks in the Nigerian Stock Exchange for the year 2009 to 2014. Financial performance was the independent variable proxy by return on equity, while dividend policy was the dependent variable measured by payout ratio and dividend yield. Panel data regression was utilized for data analysis. The study revealed a positive and significant relationship between dividend policy and financial performance.

\section{METHODOLOGY}

The study adopts the panel data approach to examine the association between dividend payout ratio, dividend retention ratio, return on assets, return on equity and earnings per share. A sample of 5 agro-allied companies listed on the Nigerian Stock Exchange was used for the period of 14 years from 2005- 2018. Dividend policy was taken as dependent variable measured by dividend payout and dividend retention ratio, while profitability as independent variable proxies by return on assets, return on equity and earnings per share. Multiple regression model was utilized to determine the effect of these different variables on dividend policy. Various researchers like Faruk (2017), Idewele and Murad (2018) utilized multiple regression in their studies. 5\% and 
$10 \%$ level of significance were used to accept or reject the null hypothesis. Two models were used in this study::

$\mathrm{Yit}=\mathrm{a}_{\mathrm{o}}+\mathrm{B}_{1} \log \mathrm{X}_{\mathrm{it}}+\mathrm{B}_{2} \log \mathrm{C}_{\mathrm{it}}+\mathrm{eit}_{\mathrm{t}}$

Where $; Y_{i t}=$ Dependent Variable of firm i for time period $\mathrm{t}$;

$\alpha_{0}=$ Constant;

$\beta_{1}=$ Coefficient of explanatory variables;

$X_{i t}=$ Explanatory variables of firm i for time period $\mathrm{t}$;

$\beta_{2}=$ Coefficient of control variables;

$C_{i t}=$ Control Variables of firm i for time period $\mathrm{t}$; and

$\varepsilon_{i t}=$ Error term of firm $\mathrm{i}$ for time period $\mathrm{t}$.

From equation 1 above, the following models were developed:

$$
\begin{aligned}
& Y_{i t}=f(D P S, D P R) \text {-- -- -- (2) } \\
& X_{i t}=f(R O A, R O E, E P S) \\
& \mathrm{C}_{\mathrm{it}}=f(\mathrm{LEV}, \mathrm{AGE})
\end{aligned}
$$

Substituting equation 2, 3 and 4 into equation 1 th e model below was formulated;

$$
\begin{aligned}
& D R R_{i t}=\alpha_{0}+\beta_{1} \log R O E_{i t}+\beta_{2} \log E P S_{i t}+\beta_{4} \log T A_{i t}+\beta_{5} \log A_{i t}+e_{i t}-(5) \\
& D P R_{i t}=\alpha_{0}+\beta_{1} \log \beta_{1} \log R O A_{i t}+\beta_{2} \log R O E_{i t}+\beta_{3} \log E P S_{i t}+\beta_{4} \log \operatorname{lEVit}_{i t}+\beta_{5} \log A_{i t}+e_{i t}-(6)
\end{aligned}
$$

Where;

$\mathrm{DRR}=$ Dividend Retention Ratio,

$\mathrm{DPR}=$ Dividend Payout Ratio,

ROA $=$ Return on Assets

ROE $=$ Return On Equity,

EPS $=$ Earnings per Share

$\mathrm{LEV}=$ Leverage

FAGE $=$ Firm Age

A priori expectations $\beta 1>0, \beta_{2}>0, \beta_{3}>0, \beta_{4}>0, \beta_{5}>0$,

Theoretically, there is an expectation that ROA, ROE, EPS, LEV and FAGE should have positive and significant impact on Dividend retention ratio and Dividend payout Ratio, which were the measured of dividend policy. To ascertain whether the data for this study fits into the above model, the variance inflation factor (VIF) test would be conducted to check the existence of multicollinearity among independent variables; the Shapiro-Wilk (W) test would be conducted to check the normality or otherwise of the data; and the Breusch Pagan test would be conducted to ascertain the existence of heteroscedasticity or not among the variables of the study.

$4 \quad$ Results and Discussions 
Print ISSN: 2052-6393(Print), Online ISSN: 2052-6407(Online)

Table 2 : Descriptive Statistics

\begin{tabular}{|l|l|l|l|l|}
\hline Variable & Mean Value & Std Dev Value & Min Value & Max Value \\
\hline DPR & 9.632 & 20.127 & 0.01 & 125.3 \\
\hline DRR & 0.154 & 0.238 & 125.782 & 909.218 \\
\hline ROA & 1.128 & 0.132 & 0.01 & 0.64 \\
\hline ROE & 1.405 & 3.292 & 0.01 & 17.56 \\
\hline EPS & 9.273 & 7.594 & 0.01 & 39.00 \\
\hline LEV & 0.873 & 0.939 & 0.01 & 3.86 \\
\hline FAGE & 20.1 & 9.791 & 5.00 & 42.00 \\
\hline
\end{tabular}

Source: Descriptive Statistic Result using STATA 14.0

Table 2 shows the depths of the descriptive statistic of the variables utilized in the study. Dividend policy was taken as the dependent variable measured by dividend payout ratio and dividend retention ratio. The dividend payout ranges from 0.01 to 125.3 with a standard deviation of 20.127 and a mean value of 9.632. The dividend retention, on the other hand, ranges from 125.782 to 909.218 with a standard deviation of 0.238 and a mean value of 0.154 . While profitability was used as independent variable proxies by return on assets, return on equity and earnings per share. The return on assets ranges from 0.01 to 0.64 with a standard deviation of 0.132 and mean value of 1.128 . The return on equity ranges from 0.01 to 17.56 with a standard deviation of 3.292 and a mean value of 1.405. The earnings per share range from 0.01 to 39.00 with a standard deviation of 7.594 and a mean value of 9.273. The Leverage as a control variable ranges from 0.01 to 3.86 with a standard deviation of 0.939 and a mean value of 0.873 , while the firm age as a control ranges from 5.00 to 42.00 with a standard deviation of 9.791 and a mean value of 20.1

\section{RESULTS OF DIAGNOSTIC AND POST ESTIMATION TESTS}

Several tests were conducted to improve the reliability and validity of the statistical results for the study. The tests are normality, multicollinearity, heteroscedasticity and Hausman specification test. 
International Journal of Business and Management Review

Vol.8, No.5, pp.28-43, August 2020

Published by ECRTD-UK

Print ISSN: 2052-6393(Print), Online ISSN: 2052-6407(Online)

Table 3: Result of Shapiro-ilk Test for Data Normality

\begin{tabular}{lcllcl}
\hline Variable & Obs & $\mathrm{W}$ & $\mathrm{V}$ & $\mathrm{Z}$ & Prob>Z \\
\hline Dpr & 70 & 0.541 & 28.304 & 7.210 & 0.000 \\
Drr & 70 & 0.667 & 20.498 & 6.568 & 0.000 \\
Roa & 70 & 0.780 & 13.520 & 5.663 & 0.000 \\
Roe & & & & & \\
& & & & & \\
Eps & 70 & & & & 0.000 \\
Lev & 70 & 0.783 & 13.002 & 5.578 & 0.000 \\
Fage & 70 & 0.955 & 13.298 & 5.627 & 0.000 \\
& 70 & 0.955 & 2.733 & 2.187 & 0.014
\end{tabular}

Source: STATA Output 2019

The Table 3 displays the P-value of all the dependent and independent variables. Both the dependent and independent variables were less than or equal to 5\% significant level showing that all the variables failed the normality test, as the tests were significant at $5 \%$ with a confidence level of $95 \%$. This suggests that the data does not fit the normal distribution. The failures in both dependent and independent variables are attributed to the following reasons: first, when the sample size of any study is insufficient, it will affects the normality of data . Second, the repetition of observations in a panel data set most times cause a problem as the observations are likely not independent which usually violates normality assumptions.. Therefore, the 5 listed agro-allied companies used in this study for 14 years is insufficient, and as such, affect the result of the normality of data.

\section{Results of Multicollinearity Test}

The Variance Inflation Factor (VIF) was examined to ascertain the existence or otherwise of multicollinearity between and among the independent variables. The results of the VIF test are shown in table 4 below:

Table 4

Results of VIF Test

\begin{tabular}{llc}
\hline Variable & VIF & Tolerance (1/VIF) \\
\hline Lev & 2.01 & 0.496 \\
Eps & 1.99 & 0.501 \\
Roa & 1.08 & 0.926 \\
Roe & 1.05 & 0.950 \\
Age & 1.01 & 0.988 \\
Mean VIF & 1.43 & \\
\hline
\end{tabular}

Source: STATA 14 output Results based on study data 
Table 4 shows that the Lev has a VIF of 2.01 at a 0.496 tolerance, showing that the data for leverage was not highly collinear with the data for other explanatory variables; eps has a VIF of 1.99 at a 0.501 tolerance, indicating that there was no perfect collinearity between earnings per share and other independent variables; roa has a VIF of 1.05 at a 0.926 tolerance, signifying that the data for return on assets was not highly collinear with the data for other independent variables; roe has a VIF of 1.05 at a 0.950 , meaning that there was no perfect collinear between return on equity with other explanatory variables; age has a VIF of 1.01 at a 0.988 , indicating that there was no perfect collinear between firm age and other explanatory variables. However, the mean VIF for all explanatory variables is 1.43. In each case, VIF is less than 4 and tolerance level is less than 2 respectively, implying that there was an absence of perfect multicollinearity among the independent variables. The mean VIF of 1.43 also attests that the models for testing the hypotheses were fit and reliable.

\section{Heteroscedasticity Tests}

The study utilized the Breusch-Pagan and Cook-Weisberg test for heteroscedasticity, while Ramsey Reset test utilizing powers of the fittest values for all the dependent variables. The reason(s) of these tests is to ascertain between the calculated chi-square value and chi-square critical value. The essence for this test is to reject the null hypothesis if the chi-square calculated is greater than the chi-square critical value. While that of Ramsey reset test is to ascertain whether there is omitted variable in the model. The results of the two tests are shown in Table 5

Table 5: Results of Hetest and Model omitted specification test

\begin{tabular}{lcccc}
\hline TEST & \multicolumn{2}{c}{ Model I } & \multicolumn{2}{c}{ Model II } \\
& STAT & P-VALUE & STAT & P-VALUE \\
\hline Hettest: Chi $^{2}$ & 28.23 & 0.000 & 4.12 & 0.042 \\
Ovtest: F-V & 1.28 & 0.289 & $0 . .65$ & 0.587 \\
\hline
\end{tabular}

Source: STATA 14 Output Results based on study data

The Table 5 displays the results of the Breusch-Pagan and Cook-Weisberg test of heteroscedasticity, a by-product of the violation of other assumptions of regression conducted to determine the heteroscedasticity state in the study. The study shows the hettest chi2 result of 28.23, which is significant at $5 \%$ level of significance (P-Value $=0.000$ ) for model I using dpr. Thus, the study accepted the null hypothesis that the data for model I using DPR is homoscedastic and rejected the alternative hypothesis. This shows that there is heteroscedasticity among dpr variables. In order to account for the presence of heteroscedasticity, the study further carried out model specification error test (omitted variable test) to attest whether the presence of heteroscedasticity test was as a result of an error in the model. Table 5 displays the result of Ramsey F-Stat (model specification error test) with Prob > F-Stat of 1.28 at 0.289 respectively. 
This suggests that the study pass model specification error test as the F-statistics is not statistically significant. This signifies that there was no omitted variable in the model.

Furthermore, Table 5 shows the result of heteroscedasticity test for model II utilizing dividend retention ratio (Drr) which indicated H-test chi 2 of 4.12 and the prob > chi ${ }^{2} 0.042$ respectively. This indicates that the null hypothesis of constant variance is captured and the model is homoscedastic. Therefore, the study show the presence of heteroscedasticity as the variation of the residual or error term is correlated and would affect the result of the study. The test of model specification error test (omitted variable test) was also carried out to ascertain whether the presence of heteroscedasticity test was as a result of an error in the model. The result as display in Table 5 using Ramsey F-Stat (model specification error test) with Prob > F-Stat of 0.65 and 0.587 respectively. This implies that the study has passed the model specification error test as the F-statistics is not statistically significant. Therefore, the null hypothesis that the model has no omitted variables is accepted while the study rejected the alternative hypothesis that the model has omitted variables

\section{Regression Results, Hausman Specification Tests and Hypotheses}

Table 6 presents the summary of the regression analysis for all the two models

\section{Table 6}

Regression Results- Model land 2

\begin{tabular}{|c|c|c|c|c|c|c|}
\hline \multirow[t]{2}{*}{ Variable } & \multicolumn{3}{|c|}{ Model1 } & \multicolumn{3}{|c|}{ Model II } \\
\hline & Coeff & Z-value & P-value & Coeff & Z-value & P-value \\
\hline ROA & 4.668 & 0.25 & 0.805 & 0.446 & 1.99 & 0.047 \\
\hline ROE & -1206 & -1.62 & 0.106 & -0.146 & -1.65 & 0.099 \\
\hline EPS & -0.288 & $-0 . .65$ & 0.517 & -0.310 & -0.59 & 0.537 \\
\hline LEV & 0.474 & 0.13 & 0.896 & 0.189 & 0.44 & 0.659 \\
\hline AGE & -0.461 & -1.87 & 0.061 & 0.989 & 0.34 & 0.735 \\
\hline CONS & 22.263 & 3.38 & 0.001 & 0.110 & 1.41 & 0.157 \\
\hline $\mathrm{R}^{2}$ & 0.0923 & & & 0.5463 & & \\
\hline Adj- $\mathrm{R}^{2}$ & 0.0214 & & & 0.5123 & & \\
\hline F-Value & 1.30 & & & 1.22 & & \\
\hline P-Value & 0.000 & & & 0.000 & & \\
\hline Haus-chi $^{2}$ & 42.10 & & & 19.70 & & \\
\hline $\mathrm{P}$-value & 0.610 & & & 0.201 & & \\
\hline
\end{tabular}

Source: STATA 14 Output based on study data

The summarized result as displayed in Table 6 indicates that model 2 is statistically significant on the account of the validity of the model. The R2 of 5463 is the multiple coefficients of determination gives the proportion of the total variation in the dependent variable explained by the explanatory variable altogether. Hence, it signifies $54.63 \%$ of the total variation in dividend policy of agro-allied companies in Nigeria caused by all the total of independent variables. The Adjusted R-square indicates that after adjusting for the degree of freedom the model explains 
International Journal of Business and Management Review

Vol.8, No.5, pp.28-43, August 2020

Published by ECRTD-UK

Print ISSN: 2052-6393(Print), Online ISSN: 2052-6407(Online)

about $51.23 \%$ of the total systematic variations in dividend policy. This variation of $51.23 \%$ in dividend policy of the listed Nigerian agro-allied companies is substantially evident for by the different explanatory variables. In addition, the $\mathrm{P}$-value of 0.0000 for the estimation confirms the fitness of the model. However, model 1 with R2 of 0.0923 with Adj-R2 of $9.23 \%$ and $2.14 \%$ respectively show the variation in dividend policy of listed agro-allied companies in Nigeria is not substantially accounted for by all the explanatory variables. Therefore, for the purpose of our analysis, model 2 will be used.

The test of model selection using Hausman specification was conducted to determine between random and fixed effects model. The result enables us to reject the fixed effect and accept random effect estimator. Therefore, the random effect model was adopted using model 2 for testing hypothesis. The bases is that model 2 is the best model that explained dividend policy compare with model 1.

Table 6 evident that the return on assets of the sample firms during the study period has a positive and significant effect on dividend policy using DPR as explained by the coefficient 0.446 and a $\mathrm{z}$-value of 1.99 at $4.7 \%$ level of significance $(\mathrm{P}-\mathrm{V}$ alue $=0.047)$. This means that in every unit increase in return on assets increases dividend policy by 0.446 . This was statistically significant at $95.3 \%$ confidence level. Return on equity has a negative and significant effect on dividend policy utilizing DPR as explained by the coefficient of -0.146 and a $\mathrm{z}$-value of -1.65 at $9.9 \%$ level of significance $(\mathrm{P}-\mathrm{Value}=0.099)$. This suggests that a unit increase in return on equity reduces dividend policy by 0.146 . This was statistically significant at $91.1 \%$ confidence level. In addition, earnings per share of the sample firms during the study period has a negative and insignificant effect on dividend policy using DPR as explained by a coefficient value of 0.310 and $z$-value of -0.59 at $55.7 \%$ level of significance $(\mathrm{P}-\mathrm{Value}=0.557)$. This shows that a one-unit rise in earnings per share decreases dividend policy by 0.310 . This was statistically insignificant at $44.3 \%$ confidence level.

The leverage has a positive and insignificant effect on dividend policy utilizing DPR as explained by a coefficient value of 0.189 and z-value of 0.44 at $65.9 \%$ level of significance (PValue $=0.659)$. This implies that every increase in leverage is insignificant increases dividend policy by 0.189 . This was statistically insignificant at $34.1 \%$ confidence level. In the same vein, firm age has a positive and insignificant effect on dividend policy using DPR as explained by a coefficient of 0.989 and $z$-value of 0.34 at $73.5 \%$ level of significance $(\mathrm{P}-\mathrm{V}$ alue $=0.735)$. This means that every unit increase in firm age is insignificant increases dividend policy by 0.989 This was statistically insignificant at $26.5 \%$ confidence level. The coefficient value of the constant (CONS) is 0.110 at $15.7 \%$ level of significance. This suggests that all other factor remains constant, the effect of dividend policy on profitability have a positive and insignificant influence. The implication of this result is that other variables in the model are relevant to have exhibited to improve on dividend policy. 


\section{Hypotheses Testing}

The first hypothesis states that return on assets has no significant effect on dividend policy of listed agro-allied companies in Nigeria. The return on assets of sample firms during the study period has a positive and significant effect on dividend policy. Thus, a unit increase in return on assets is significantly affected dividend policy and vice versa. This suggests that the return on assets has the probability of influencing dividend policy. This provides us with evidence of rejecting the null hypothesis and accepting the alternative that return on assets has a significant effect on the dividend policy of listed agro-allied companies in Nigeria. This finding is consistent with Akani and Swenene (2012), Chauhan et al. (2019), who find a positive and significant effect of profitability on dividend policy. The finding is contrary to the finding of Calistus (2015); Geoffrey (2017), who find a negative and significant effect of profitability on dividend policy.

The second hypothesis states that return on equity has no significant effect on dividend policy of listed agro-allied companies in Nigeria. The return on equity of listed agro-allied companies in Nigeria during the study period has a negative and significant effect on dividend policy. This provides us with evidence of rejecting the null hypothesis and accepting the alternative hypothesis that return on equity has a significant effect on the dividend policy of listed agroallied companies in Nigeria. This finding is in conformity with the finding of Faruk (2017), who also find a negative and significant effect of profitability on dividend policy. This finding contradicts the finding of Idewele and Murad (2019), who find a positive and significant effect of profitability on dividend policy.

The third hypothesis states that the earnings per share have no significant effect on dividend policy of listed agro-allied companies in Nigeria. In view of the regression result as presented in table 6, the earnings per share have a negative and insignificant effect on dividend policy. This provides us with evidence of accepting the null hypothesis and rejecting the alternative hypothesis that the earnings per share have no significant effect on dividend policy of listed agro-allied companies in Nigeria. This finding is in agreement with the finding of Evans (2016), who also find a negative and insignificant effect of the profitability on dividend policy. This finding is contrary to the finding of Monoarfa (2018), who find a negative and significant effect of the profitability on dividend policy..

\section{CONCLUSION AND RECOMMENDATIONS}

In view of the above findings, the study concludes as follows:

The return on assets has a positive and significant effect on dividend policy of listed agro-allied companies in Nigeria.

The return on equity has a negative and significant effect on dividend policy of listed agro-allied companies in Nigeria.

The earnings per share has a negative and insignificant effect on dividend policy of listed agro-allied companies in Nigeria. 
International Journal of Business and Management Review

Vol.8, No.5, pp.28-43, August 2020

Published by ECRTD-UK

Print ISSN: 2052-6393(Print), Online ISSN: 2052-6407(Online)

From the conclusions based on the analysis examined, the study makes the following recommendations:

First, the use of company assets should be encouraged as it is seen to yield more profits thereby improves dividend policy of listed agro-allied companies in Nigeria.

Second, the use of company equity should be discouraged as it seen to reduce dividend policy of listed agro-allied companies in Nigeria during the study period.

Finally, the use of earnings per share should be discouraged as it does not contributes meaningful to dividend policy of listed agro-allied companies in Nigeria during the study period

\section{References}

Abu, S.O., \& Emmanuel, A (2019). Effect of dividend policy on share price of Listed Conglomerate Firms in Nigeria. African Journal of Management Research, 26, 39-55.

Akani, H.W., \& Swenene, Y (2016)Dividend policy and the profitability of selected Quoted Manufacturing Firms in Nigeria: An empirical analysis. Journal of Finance and Accounting, 4 (4), 212-234.

Anandasayanan, S., \& Velnampy, T (2016). Dividend policy and corporate profitability: Econometric analysis of Listed Manufacturing Firms in Sri Lanka. International Journal of Commerce and Management Research, 2 (1), 53-58.

Black, F. \& Scholes, M. (1974). The Effect of Dividend Yield and Dividend Policy on Common Stock Prices and Returns. Journal of Financial Economics 1-22

Brigham, E.F. (1995), Fundamentals of Financial Management, New York; McGraw Hill in Compsey

Calistus, W.W., Mohammed, S.M., \& David, O (2018). Effect of liquidity on financial performance of the Sugar Industry in Kenya. International Journal of Education and Research, 6 (6), 29-44.

Chauhan, J., Ansari, M.S., Taqi, M.S \& Ajmal, M (2019). Dividend policy and its impact on performance on India Information Technology (IT) Companies. International Journal of Finance and Accounting, 8 (1), 36-42.

Easterbrook, F.H (1984). Two agency, cost explanation of dividends. The American Economic Review, 74 (4), 650-659.

Enekwe, C.I., Nweze, A.U., \& Agu, C.I (2015). The effect of dividend payout on performance evaluation: Evidence of Quoted Cement Companies in Nigeria. European Journal of Accounting, Auditing and Finance, 3 (11), 40-59.

Evans, F.N., \& Hadrat, Y (2016). Investigating the effect of dividend policy on the wealth of stockholders of Listed Companies on the Ghana Stock Exchange. International Journal of Economic and Finance, 6 (7), 47-54.

Faraz, Z., Ishfaq, S., \& Khan, A (2017). Dividend policy and shareholders' wealth: Evidence from Cement Sector of Pakistan. International Journal of Information, Business and Management, 9 (3), 27-40.

Geoffrey, I., Mbithi, M., \& Musiego, M (2017). Determinants of shareholders' wealth among Listed Financial Firms' on the Nairobi Securities Exchange. International Journal of Management and Commerce Innovation, 4 (4), 374-388. 
Vol.8, No.5, pp.28-43, August 2020 Published by ECRTD-UK

Print ISSN: 2052-6393(Print), Online ISSN: 2052-6407(Online)

Idewele, I.O.E., \& Murad, B.A (2019). Dividend policy and financial performance: A study of selected Deposit Money Banks in Nigeria. African Journal of Business Management, 13 (7), 239-255.

Jensen, M.C., \& Meckling, W (1976). Theory of the firm: Managerial behavior, agency costs, and ownership structure. Journal of Financial Economics, 3: 305-60

Litzenberger, R. H \& Ramaswamy (1979). The effect of personal taxes and dividends on capital asset prices: Theory and empirical evidence. Journal of Financial Economics, 7(2), 163195.

Matengo, M (2008). The relationship between corporate governance practices and performance: The Case of Banking Firms in Kenya. University of Nairobi.

Modigliani, F \& Miller, M. (1961). Dividend policy, growth and the valuation of shares, Journal of Business 34, 411-433.

Monoarfa, R (2018). The role of profitability in mediating the effect of dividend policy and company size on company value. Business and Management Studies, 4 (2), 46-65.

Poterba, J., \& Lawrence, S (1988). Mean reversion in stock prices: Evidence and implication NBER Working paper 2343, Cambridge NA

Ross, S.A.,Westerfield, R.W., \& Jaffe, J (2002). Corporate finance (6 $6^{\text {th }}$ ed) McGraw-Hill Companies

Samad, A., \& Hassan, M. C (2000). The performance of Malaysian Islamic Banking during 1984-1987; An exploratory study. International Journal of Islamic Finance Services, 1(3), 15-32.

Uwuigbe,U ,. Jafaru, J \& Ajayi, A (2013). Dividend policy and firm performance: A study of listed firms in Nigeria. Accounting and Management Information Systems, 11(3), 442454.

Van Horne, J. C, \& Wachowicz, J. M (2005). Fundamentals of financial management $12^{\text {th }}$ Edition. Pearson Education Limited, Prentice Hall, New York 